\title{
QASHAS AND AMTSAL NORMATIVE STUDY: ANALYSIS OF ISLAMIC EDUCATION IMPLEMENTATION
}

\author{
Yazida Ichsan*, Unik Hanifah Salsabila, Difa'ul Husna \\ Faculty of Islamic Religion, Universitas Ahmad Dahlan \\ Jl. Kapas No. 9, Daerah Istimewa Yogyakarta, Indonesia. 55166 \\ *E-mail: yazida.ichsan@pai.uad.ac.id
}

\begin{abstract}
Amtsal and qashas in the Qur'an can apply as a method and material. The technique uses a systematic way to achieve specific goals-the content as a study discussion or as the theme of the debate in individual learning. The application of amtsal and qashas in the Qur'an would need to use integrating normative tools with several approaches: psychology, linguistics, science, anthropology, sociology as benchmarks in learning. The application of methods in particular operational and operational periods, qashas and amtsal can be presented as a descriptive narrative that presented with a gripping narration, diction and vocals that will make students very interested and can take the lessons in question. The development of amtsal and qashas information technology can also modify with socio drama, visual, and video. However, in subsequent events a child's cognitive development in the conceptual operational phase uses historical, sociological, legal, anthropological, scientific and technological perspectives, become something that needs to use.
\end{abstract}

Keywords: amtsal, qashas, Islamic education

\begin{abstract}
Abstrak: Amtsal dan qashas di dalam Al-Qur'an dapat diterapkan sebagai metode dan materi. Metode digunakan sebagai sebuah cara yang sistematis untuk mencapai tujuan tertentu. Adapun materi sebagai sebuah kajian pembahasan ataupun sebagai tema pembahasan di dalam pembelajaran tertentu. Penerapan amtsal dan qashas dalam Al-Qur'an kiranya perlu menggunakan mengintegrasikan antara perangkat normative dengan beberapa pendekatan: psikologi, kebahasaan, scientific, antropologi, sosiologi sebagai tolak ukur di dalam pembelajaran. Penerapan metode pada masa pra-operasional dan operasional kongkrit, qashas dan amtsal dapat di sajikan sebagai sebuah narasi deskriptif yang disajikan dengan narasi, diksi dan vocal yang menarik akan membuat peserta didik sangat tertarik dan dapat mengambil pelajaran yang dimaksud. Berkembangnya teknologi informasi amtsal dan qashas juga dapat dimodifikasi dengan sosiodrama, visual, maupun video. Akan tetapi, pada perkembangan berikutnya perkembangan kognitif seorang anak pada fase operasional abstrak penggunaan perspektif sejarah, sosiologis, hukum, antropologis, ilmu pengetahuan dan teknologi. menjadi hal yang sangat perlu digunakan.
\end{abstract}

Kata Kunci: amtsal, qashas, pendidikan Islam

\section{Introduction}

The development of technology in the current millennial era provides new challenges and press perspectives in the world of Islamic education. The problems faced are even more complicated as a result of massive and very rapid changes. This enormous change also has implications for the issues of learning and teaching. Today's students will even get information more quickly from electronic media compared to information provided by educators. The emergence of new methods that are more modern and dynamic has begun to eliminate practices that are considered conservative. The lecture, story, story history, and becomes old-fashioned and irrelevant to current conditions. It will even abandon because they are deemed ineffective and are less desirable for educators and students. This assumption implies that both the story and the parable in the Qur'an need to package in such away.

These conditions have an impact on Islamic education. Where the stories and analogies or parables that exist in the Qur'an as a method and content of things and are not so attractive of people today, so it needs clear thinking where amtsal. Qashas are there in the Qur'an, it is not only a form of narration and story, but it also raises awareness and implements critical reasoning that has implications for both individual and social life. The current paradigm, amtsal and qashas is conveyed one way from the educator to the students where the educator only conveys information, news and facts without any more in-depth analysis related to current life.

Amtsal and qashas themselves are an integral part of the miracles of the Qur'an, where M. Quraish Shihab explains that there are three aspects of wonders in the Qur'an, namely: Aspects of linguistics, 
scientific cues and unseen preaching. Kuntowijiyo described that the concept of the Qur'an contained historical and amtsal stories (parables to reflect on wisdom) through contemplation of past events and events through metaphors providing hidden intelligence, human beings. We invited to contemplate the nature and meaning of life. As part of the Qur'an, amtsal and qashas in the Qur'an according to the author has elements of scientific cues and unseen news that need to study with a scientific approach wherein education there is research that more deeply related to this matter.

Amtsal in the Qur'an needs to be studied with several perspectives so that we can find out why Allah gives a parable with an object or creature and what factors cause Allah to provide a parable with specific material or animal. Whereas in qashas, we can find teachings and analyzes related to past events to be drawn in current events so that we can obtain values, wisdom and scientific knowledge conveyed in the A -Qur'an. Presumably, we need to implement the urgency of amtsal and qashas as a method and study so that the information given by the Qur'an becomes a spiritual, moral, wisdom as well as a science by ibrah.

Reference for students with several perspectives and innovations to answer several cases which occurs by reflecting on events and parables. That has described in the Qur'an. This paradigm is something that needs to be reviewed in the world of Islamic education by involving interdisciplinary knowledge in several perspectives. Manna 'Khalil Al-Qattaan defined qashas derived from the word al-qassu, which means to seek or follow in the footsteps also interpreted as news in a sequence. In terminology is the preaching of the Qur'an about matters of the past people. Prophecy (prophecy) before and the events that have occurred. Of course, in the stories that have mentioned in the Qur'an, it implies that this event is a very extraordinary event experienced by a people, individuals or creatures as a lesson (ibrah) and we need to analyze and relate it to events currently.

The need for assessment is as an effort to rediscover how the causes of the event occurred. In addition, the story in the Qur'an has an essential purpose, which is to teach, guide, and remind us to follow God's law. The object that told in the Qur'an, namely First, Something that has happened in the real world, Second, Something that occurs not in the real world (empirical) but the mind through dreams. Third, something that is not an event, but teachings and guidance. Yunahar Ilyas divides the kinds of stories in the Qur'an into three parts: the stories of the prophets and apostles, the stories of the people, figures or individuals in the past events, the stories that occurred in the time of the prophet Muhammad SAW. Qashas in the Qur'an not only seen as a sequence of events, historical facts, or 'ibroh which needs contemplation.

However, an understanding of a story or a parable that currently tends not to explore in more depth. The meaning and object that becomes a parable or the story that presented. The purpose of the scope of the story that is in the Qur'an also needs a scientific and continuous study to produce specific knowledge. M. Quraish Shihab explained that there were two ulama 'attitudes in addressing the story in the Qur'an: first, understanding all events in the Qur'an that happened in the real world. Second, know that some of the stories in the Qur'an are symbolic that never arrived in the real world, but their contents are right and true. The scholars' argued by transferring the intrinsic meaning of lafazh to the purpose of majazy.

\section{A. Amtsal in the Qur'an}

Amtsal is a form of jama' matsal which has many meanings, namely similarity, balance, level of something, unusual or astonishing, and lessons that can learn besides meaning. In the Qur'an, matsal is using in the sense of a peculiar nature or condition; besides that, it is not infrequently also used in the spirit of similarity. Ibn al-Qayyim defines amtsal by liking something with something else in terms of the law, and bringing something abstract (ma'qul) to the senses (concrete, mahsus), or bringing one of the two mahsus closer to each other and considering one of them being like the others. If the definition proposed by amtsal experts says that the matsal is to equate the situation with the state of something else, expression, can be in the form of isti'arah, tasybih, the Sharil, or a short verse with meaning in (i'jaz).

Matsal will bring the mumatsalah picture in the mind of the person who is speaking, the call to 
think logically and arrive at its peak with the reason offered is faith (al-Hujiah al-Burhaniyah). Always do good and try to beautify yourself, if not push to avoid things that are bad and negative. Matsal who gives encouragement and attitude. Like to do good, or vice versa by arousing fear; to do things that are forbidden. Matsal is used to praise or condemn something done, in addition to expressing admiration or contempt. Matsal is used to sharpen human reasoning power, to move their ability to have a sense so that people will feel compelled to do so (Ali, 1996). In Amtsal itself is divided into two, namely short sentences in the Qur'an whose meaning is similar to proverbs used in society. Short sentences of the Koran which later became proverbs. The types of amtsal are as follows:

1. Amtsal musarrahah, which is explained by the mass of lafaz or something that shows tasybih

2. Amtsal kaminah in it did not state lafaz tamtsil (analogy). Still, it shows a beautiful meaning, attractive, in the density of the editor, and has a different effect when transferred to something similar to it.

3. Amtsal Mursalah that is a free sentence that does not use clear tasybih lafaz.

\section{B. The Amtsal and Qashah Dimensions in Learning}

Learning as a process is nothing but a planned, systematic process and seeks to develop the value of knowledge, attitude (spiritual and social) and skills. Educators should note that amtsal and qashas usually emphasize approaches, and experience is nothing more than information that is sometimes difficult to explain with scientific devices so that substantial information can sometimes not be delivered optimally. Besides, amtsal and qasas in the Koran can apply as a method and material. This method used as a systematic way to achieve specific goals. Content as a discussion of learning or as a theme of debate in particular education.

The application of amtsal and qashas in the Qur'an is needed to use normative tools that integrated with several approaches: psychology, linguistics, science, anthropology, sociology as benchmarks in learning. The application of methods in the pre-operational and concrete operational periods, qashas and amtsal can be presented as descriptive narratives presented with compelling, diction and vocal stories that will make students very interested and can take the intended lesson. The development of amtsal and qashas information technology can also modify with socio drama, visual, and video.

However, in subsequent developments, the cognitive development of children in the abstract operational phase uses historical perspectives, social sociology, law, anthropology, science and technology. Into something that needs to use. His attitude is used to try to explore the deeper meaning of stories and amtsal in the Koran and discover new knowledge implicit in amtsal and qashas and can find out why Allah informs certain parables and stories. Educational entities today emphasize more on the normative aspects in which the historical aspects explained by the Qur'an are somewhat rule out. Parable (amtsal) in the Koran that provides scientific cues and policy values at this time is still very shallow understood so that the need for transcendent scientific studies so that in science and wisdom we can understand the purpose of the subject and object of parables.

Religious truths that are built based on ethical principles whose fact cannot refute the need to be supported by philosophical and scientific truths to base qashas and amtsal in the Koran. Qashas and Amtsal are not only projected as concepts but as objects of scientific study which, besides being trusted in their truthfulness, need to find their scientific meaning and cues. Senses and reason enable humans to unravel the mysteries and reality of the universe. At first, observes a phenomenon, so it makes sense to analyze, abstraction, and construct a theory of the event. As a result, knowledge is shared and accepted by almost everyone, including religious people who have a hold of the holy book. In the field of education, amtsal as a method itself has pedagogical objectives, namely: Bring meaning closer to understanding.

Stimulating the impressions and messages related to the meaning implicit in the parable, which inspires and fosters various feelings of divinity. Educate the reasons for logical thinking and use reasonable and healthy qiyas (syllogism). This parable is a motive that encourages feelings of life in instinct, which then arouses desire and inspires someone to do good deeds and avoid all evil. It must that science is a type of knowledge obtained through research on empirical objects. Whether the logic of empirical evidence determines a scientific theory or not. Philosophy is a type of human experience that 
is only logical about objects that are abstract and logically accountable. Mystical knowledge of supersensible, supranational or maturational abstract objects. This knowledge obtained through taste and trust.

\section{Conclusion}

Application of amtsal and qashas in the Qur'an would need to use integrating normative tools with several approaches: psychology, linguistics, science, anthropology, sociology as benchmarks in learning.

\section{References}

Ali, Furnham. 2019. "Culture Shock: A Review of the Literature for Practitioners." Psychology 10(13):1832-1855. doi:10.4236/Psych.2019.1013119.

Cooke, Bernard and Macy. G. 2020. Symbol and Ritual: An Introduction

Ik-Msda-K, Isybiliya. 1999. Tafsir Al-Qur'an Al-'Az̧im.

Rohman I. 2016. Tafsir Al-Qur'an Bi Al-Qur'an: Sectarian Tendencies in Al-Tabataba'i's Al-Mizan and Al-Shanqiti's Adwa'al-Bayan. http://Repository.Uinjkt.Ac.Id/Dspace/Handle/123456789/49927. Accessed April 30, 2020. 